\title{
Methylene blue dye removal using Sphagnum palustre L. Bog-moss as a reusable biosorbent
}

\author{
Nalan Oya SAN KESKIN* (iD, Guray UYAR ${ }^{1}$ \\ ${ }^{I}$ Polatl Science and Literature Faculty, Biology Department, Ankara Hacı Bayram Veli University, \\ 06900, Ankara, TURKEY
}

\begin{abstract}
Received: 11.10.2018
Revised: 06.11.2018

Accepted: 04.12.2018

Abstract

In this study, Sphagnum palustre L. Bog-moss (SPM) was used as a reusable and economical biomaterial for the removal of methylene blue (MB). The effects of different $\mathrm{pH}$, temperature, time, static/shaking conditions, adsorbent amount and concentration of dye were investigated. We evaluated that moss can almost completely remove $(99.5 \%) \mathrm{MB}$ at low $\left(50 \mathrm{mg} \mathrm{L}^{-1}\right)$ concentration within $1 \mathrm{~h}$, while $85 \%$ dye removal was observed at approximately higher concentration $500 \mathrm{mg} \mathrm{L}^{-1}$. The adsorption isotherm data were fitted well to the Langmuir isotherm. Furthermore, reusability tests showed that $S$. palustre could be used in at least six decolorization steps with high removal efficiency. After the $6^{\text {th }}$ reuse step, the decolorization rate of the MB was found to be $65 \pm 0.2 \%$. As a result, Sphagnum moss could be applicable for the decolorization due to their versatility and reusability.
\end{abstract}

Key words: Decolarization, dye, isotherm, moss, reusability

\section{Metilen Mavisi Boyasının Giderilmesinde Tekrar Kullanılabilir Biyosorbent Olarak Sphagnum palustre L. Karayosununun Kullanılması}

$\ddot{\mathrm{O} z}$

Bu çalışmada, Sphagnum palustre L. karayosunu (SPM) metilen mavisi (MB) gideriminde tekrar kullanılabilir ve ekonomik bir biyomateryal olarak kullanılmıştır. Farklı pH, sıcaklık, zaman, statik / çalkalama koşulları, adsorban miktarı ve boya konsantrasyonunun boyar madde giderimine etkileri araştırılmıştır. Karayosunu, düşük konsantrasyon boyar maddeyi $\left(50 \mathrm{mg} \mathrm{L}^{-1}\right) 1$ saat içinde neredeyse tamamını (\% 99,5) giderirken, $500 \mathrm{mg} \mathrm{L}^{-1}$ yüksek konsantrasyonu \%85 oranında giderdiği belirlenmiştir. Adsorpsiyon izoterm verilerinin Langmuir izotermi ile uygun olduğu bulunmuştur. Bu duruma ilaveten, tekrar kullanılabilirlik deneyleri S. palustre'nin en az altı renk giderimi işleminde yüksek giderim verimi ile kullanıldığını göstermiştir. Altıncı tekrar kullanılabilirlik testinde, metilen mavisinin renk giderim verimi \% $65 \pm 0.2$ olarak bulunmuştur. Bu sonuçlar, çok yönlülüğü ve yeniden kullanılabilirliği nedeniyle Sphagnum'un renk giderimi uygulamasında kullanılabileceğini önermektedir.

Anahtar kelimeler: Renk giderimi, boyar madde, izoterm, yosun, tekrar kullanılabilirlik

\footnotetext{
* Corresponding author: nalan.san@hbv.edu.tr (C) 2019 All rights reserved / Tüm haklarl saklıdır.

To cite this article: San Keskin N.O. Uyar G. 2019. Methylene blue dye removal using Sphagnum palustre L. Bogmoss as a reusable biosorbent. Anatolian Bryology. 5:1, 1-7.

(c) $(1)$ ( ) This work is licensed under a Creative Commons Attribution-NonCommercial 4.0 International License.
} 


\section{Introduction}

Significant amount of wastewater has been released into the environment after industrialization and urbanization period (Saeed et al., 2009; Malik, 2014; San Keskin et al., 2015). Synthetic dyes/pigments in many industries such as textile, plastics, leather tanning, paper production, cosmetics, and hair colorings are major causes of environmental pollution (Zaghbani et al., 2007; Turabık and Gozmen, 2013). After dye applications, about 2$50 \%$ of the dyestuff released into the environment via industrial wastewater (Atafar et al., 2010). Even above the concentration of $1 \mathrm{mg}$ $\mathrm{L}^{-1}$ of dye is enough to be visible by human eye, in general, textile wastewaters contain 10 to 50 $\mathrm{mg} \mathrm{L}^{-1}$ of industrial pigments. Dyes affect photosynthesis processes and change the biological cycles. At present, several technologies such as chemical precipitation, ion exchange, solvent extraction, membrane separation and adsorption have been developed to remove dyes from wastewater (Raghu et al., 2009; Saeed et al., 2010; Lee et al., 2011; Kazemi et al., 2013; Ghaedi and Mosallanejad, 2014; Hajati et al., 2014; Soni et al., 2014; Toor et al., 2015). Adsorption is considered as an efficient approach due to its low cost, and easy operation among various other water treatment methods (Chakraborty et al., 2005; Wang et al., 2005). Thus, decolorization technologies such as adsorption are utilized. Several low cost adsorbents such as sawdust (Garg et al., 2003), rice husk (Gupta et al., 2009) and ash (Marrakchi et al., 2017) have been examined on the possibility study to lower dye concentrations and used to water treatment.

In this study, synthetic dye methylene blue (MB) is selected as model contaminants which is used $\mathrm{MB}$ is used as a coloring agent like paper, cottons, hair, wools and paper stock (Du et al., 2016) in order to evaluate the sorption efficiency of the Turkish $S$. palustre moss from aqueous solutions. Due to its characteristic as a highly porous, polar material, having cellulose and lignin as its main components, moss has been reported as a low cost sorbent for efficient removal of dye water pollutants (Contreras et al., 2007; Gupta et al., 2009).

Removal of MB dye was investigated under batch conditions with various process parameters, such as $\mathrm{pH}$ of solution, temperature, static/shaking conditions, adsorbent amount, concentration and contact time, were considered. Finally, the reusability of SPM was tested. To understand the mechanism of dye sorption using moss as the adsorbent, the sorption data were tested fitted to a number of isotherm models.

\section{Materials and Methods}

Sphagnum includes approximately 120 species, commonly known from boggy wetland habitats (Daniels and Eddy, 1985). Currently, 24 taxa in Sphagnum have been recorded for Turkey (Ören et al., 2017). Sphagnum species in Turkey were usually known from eastern Black Sea region. Nevertheless, using blunt-leaved bog moss (Sphagnum palustre L.) in this research was collected from the swampy lands near to alpine meadows at Sogucak plateau, alt. c. $1075 \mathrm{~m},\left(40^{\circ}\right.$ $\left.36 ' 21^{\prime \prime} \mathrm{N}, 30^{\circ} 11^{\prime \prime} 27^{\prime \prime} \mathrm{E}\right),(1075 \mathrm{~m})$ on 28 May 2015, in Samanlı Mountains where extend from western edge of the Armutlu Peninsula in Yalova province to Geyve gorge of Sakarya province in north-western of Turkey. Voucher specimens were deposited in Ankara Hacı Bayram Veli University, Polatlı Science and Literature Faculty, Department of Biology ( $A H B V B R Y$ 1146).

Batch adsorption experiments were performed in by shaking the required amount of moss $(0.5 \mathrm{~g})$ with $100 \mathrm{~mL} \mathrm{MB}$ aqueous solutions, at a $25 \pm 1$ ${ }^{\circ} \mathrm{C}$. After a specified contact time period, residual concentration of $\mathrm{MB}$ in solution was spectrophotometrically at $\lambda=665 \mathrm{~nm}$ (UV-VIS Spectrophotometer, Shimadzu) (San et al., 2014).

The decolorization experiments in batch mode were accomplish at various contact time (0-5 hours), different $\mathrm{pH}(\mathrm{pH} 2-\mathrm{pH} 12)$, different temperatures vary on $25{ }^{\circ} \mathrm{C}$ to $40{ }^{\circ} \mathrm{C}$, static/shaking conditions such as $0 \mathrm{rpm}, 100 \mathrm{rpm}$, $200 \mathrm{rpm}$, adsorbent amount of $0.1 \mathrm{~g}$ to $2 \mathrm{~g}$ and dye concentrations $50 \mathrm{ppm}$ to $500 \mathrm{ppm}$. After inoculation, every 30 minutes, aliquots of the culture solution were withdrawn and used for analysis. Experiments were repeated in triplicates.

Decolorization percentage was calculated from below formula:

$=\frac{\begin{array}{c}\% \text { Decolorization } \\ \text { Initial absorbance value }- \text { final absorbance value }\end{array}}{\text { Initial absorbance value }}$

The amount of MB adsorbed by moss, $q$ e (mg g ${ }^{1}$ ), was calculated by the following equation:

$$
q e=\frac{(\mathrm{Co}-\mathrm{Ce}) \mathrm{V}}{\mathrm{m}}
$$


where $\mathrm{C}_{0}$ is initial and $\mathrm{Ce}$ is equilibrium concentrations of dye solution. $\mathrm{V}$ is the total volume of the dye solution, and $\mathrm{m}$ is the mass of moss used (Balan et al., 2009).

When the system is a state of equilibrium, determining the distribution of $\mathrm{MB}$ between moss surface and the liquid phase is important for establishing the capacity of the moss. The adsorption equilibrium data were fitted into four different isotherm models using Isofit software (Wagner et al., 2005).

Small moss sample was prepared for SEM analyses. The samples were coated with 5-10 nm layer of gold-palladium and analyzed using SEM microcopy (FEI Instruments, USA).
The reusability of the moss was performed 6 times at $200 \mathrm{rpm}$ and $25{ }^{\circ} \mathrm{C}$ for 1 hour. Dye concentrations were measured at the beginning $(0 \mathrm{~h})$ and at the end of $1 \mathrm{~h}$.

\section{Findings}

Hemmati et al., (2017) used acid modified Spagnum as a biosorbent for removal of malachite green. In response to this, $S$. palustre was used directly in our studies with no further preperations.

SEM image of the pore structure of $S$. palustre is shown in Figure 1. Due to highly pore structure, $S$. palustre has the unique ability to hold up to 20 times its weight in water (Schofield, 2001). These structures provide moss to extremely large surface area, and hold water/moisture well.

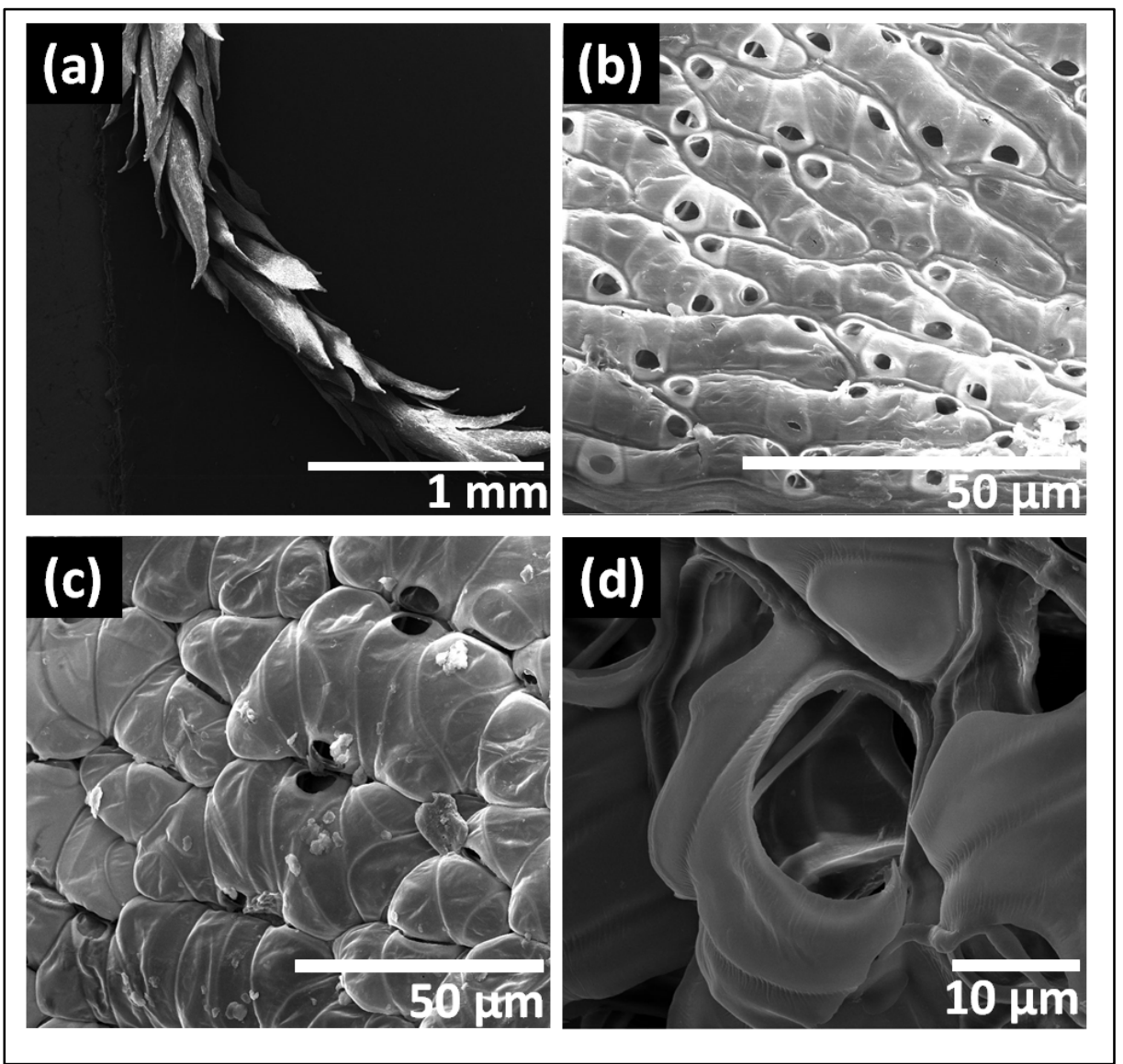

Figure 1. SEM images of the pore structure of S. palustre collected from Samanlı mountains.

Selecting the appropriate $\mathrm{pH}$, contact time, static/shaking conditions, temperature and amount of moss for achieving maximum efficiency in the decolorization of dye by adsorption might be essential. After $1 \mathrm{~h}$ incubation, $\mathrm{pH}$ value effect on dye decolorization was determined. The experiments were performed at $\mathrm{pH}$ 2.0-12.0. As shown in Fig. 2a, the lowest uptake yields were observed at $\mathrm{pH} 2.0$ and $\mathrm{pH} \mathrm{12,} \mathrm{which} \mathrm{correspond} \mathrm{to} \mathrm{strongly} \mathrm{acidic}$ and basic conditions respectively. The maximum uptake yield was $99.5 \% \pm 0.06$ at $\mathrm{pH} 4$. In addition, decolorization yields were still high at $\mathrm{pH} 5$ and $\mathrm{pH}$ 6. As a result, an initial $\mathrm{pH}$ in the range of 3.0-6.0 was favorable for the dye removal by the adsorbent. 
The effect of time on the decolorization process were studied from 15 minutes to 5 hours at 50 $\mathrm{mg} \mathrm{L}^{-1}$ initial $\mathrm{MB}$ at $\mathrm{pH} 4.0$ at $25^{\circ} \mathrm{C}$. As seen in Figure $2 \mathrm{~b}$, the decolorization increased during the first $1 \mathrm{~h}$ and $99.5 \pm 0.06 \%$ of $\mathrm{MB}$ was removed from the solution at $200 \mathrm{rpm}$. After $1 \mathrm{~h}$, reached a constant value when equilibrium was established for both $100 \mathrm{rpm}$ and $200 \mathrm{rpm}$. For static condition $(0 \mathrm{rpm})$ equilibrium reach to constant value after 180 minutes of incubation. Optimum shaking time found $1 \mathrm{~h}$, which was used for all further adsorption studies. Adsorbent decolorization ability was significantly enhanced to $98.8 \pm 0.06 \%$ for $100 \mathrm{rpm}$ and $99.5 \pm 0.06 \%$ for $200 \mathrm{rpm}$.

Due to direct effect on adsorption process, temperature is significant physico-chemical process parameter. The simultaneous decolorization of $\mathrm{MB}$ at different temperatures such as $25^{\circ} \mathrm{C}, 30{ }^{\circ} \mathrm{C}$ and $40^{\circ} \mathrm{C}$ was shown in Figure 2c. Whereas the percentage of removal after $1 \mathrm{~h}$ was found to be comparatively low at $40{ }^{\circ} \mathrm{C}$, it increased to a higher level at $30{ }^{\circ} \mathrm{C}$ and reaches maximum rate $99.6 \pm 0.06 \%$ for $25{ }^{\circ} \mathrm{C}$. Temperature analysis indicates that the adsorption is an exothermic process (Argun et al., 2008). When temperature increase adsorptive forces between the dye and adsorbent surfaceactive sites decrease as a result of decreasing the amount of adsorption. The results of the dependence of MB adsorption on the amount of moss was shown in Figure 2d.

Data showed that, there is parallel relationship between amount of dye and dye concentrations cause dyes adsorption increased with increasing the amount of moss. At the end, value reached a constant value when equilibrium was established. $0.5 \mathrm{~g}$ was found to be the optimum amount that used for all further experiments.

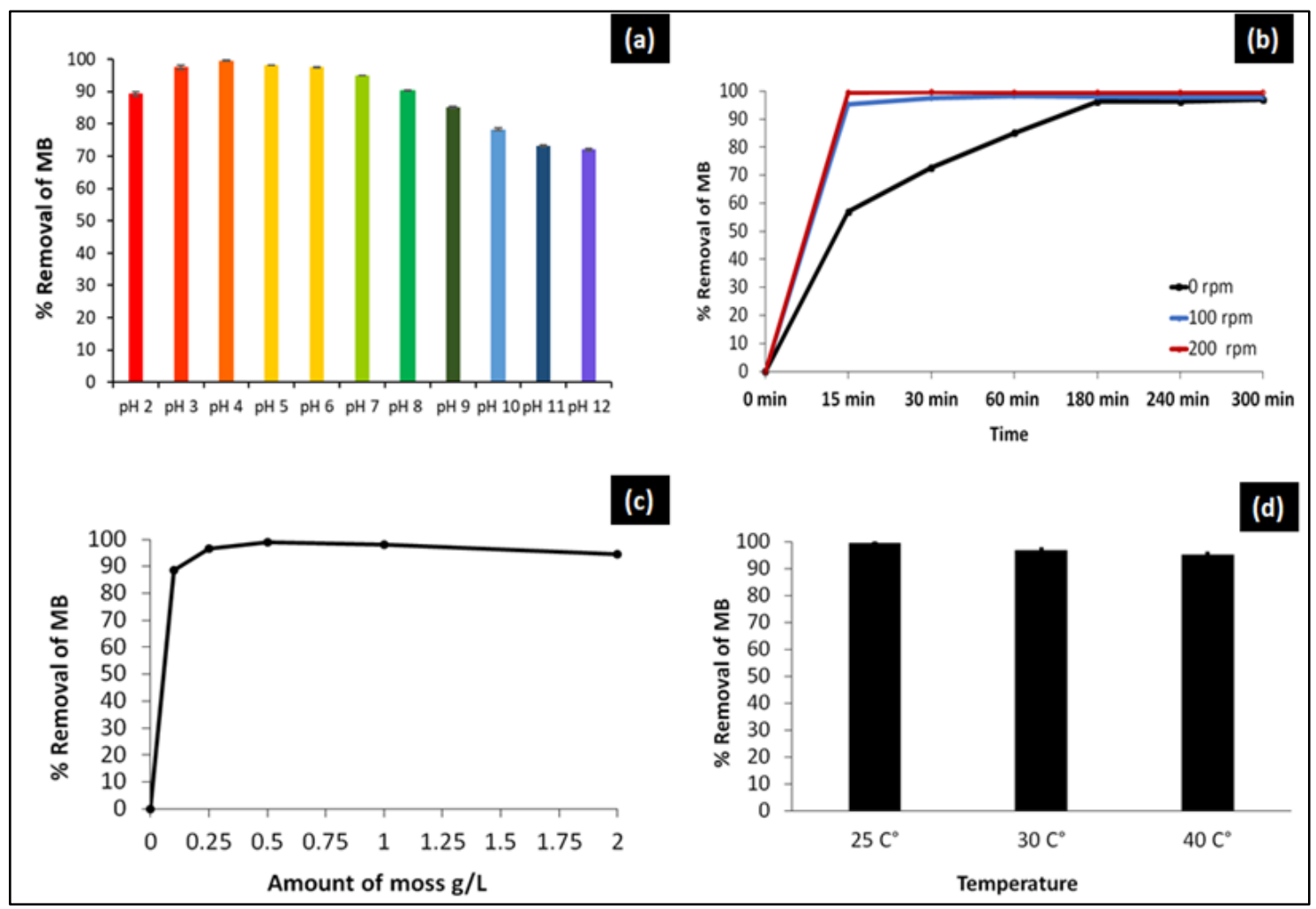

Figure 2. The effect of (a) pH (b) contact time and static/shaking conditions (c) amount of moss and (d) temperature on the decolorization yield of the moss in the $50 \mathrm{mg} \mathrm{L}^{-1} \mathrm{MB}$ dye.

Initial dye concentration effect on the decolorization process was explored by using different dye concentrations such as 50, 100, 250 and $500 \mathrm{mg} \mathrm{L}^{-1}$. As given in Figure 3, MB decolorization was achieved $97.04 \pm 0.1 \%$ decolorization at $100 \mathrm{mg} \mathrm{L}^{-1}$. For $250 \mathrm{mg} \mathrm{L}^{-1}$ dye concentration, the decolorization capacity was
$96.23 \pm 0.2 \%$. When dye concentration was increased up to high concentration as $500 \mathrm{mg} \mathrm{L}^{-1}$, the decolorization capacity was decreased to 85 $\pm 1.9 \%$. As it was clearly seen in Figure S1 that after decolorization process, decolorization yields of the moss cells were still significantly higher. 


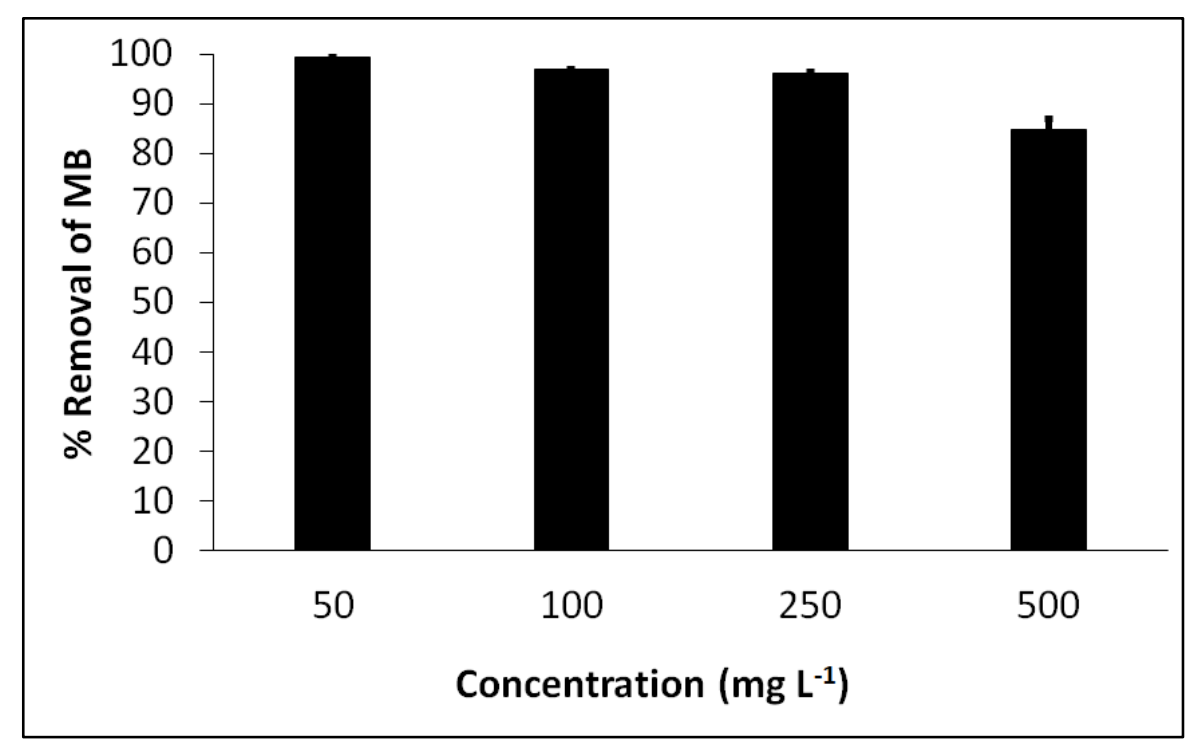

Figure 3. The effect of initial dye concentration on the decolorization yield of the moss in the $50 \mathrm{mg} \mathrm{L}^{-1}$ dye of $\mathrm{MB}$ (pH 4; Temp: $25^{\circ} \mathrm{C}$; stirring rate: $200 \mathrm{rpm}$ ).

From the point of view of bioremoval research it was essential to study the reusability of the microorganisms. Moss dye decolorization capability was tested for six cycles of reuse (Figure 4). Figure 4a showed the MB decolorization efficiency for cycles. At the end of the first cycles, \% removal of dyes was observed as $96.5 \pm 0.02 \%$. For the 3 th cycle, the dyes decolorization decrease to $89.4 \pm 0.5 \%$.
The cycle numbers of reusability are a significant issue for applications. $65.09 \pm 0.2 \%$ of the dye decolorization was obtained for the $6^{\text {th }}$ cycle for MB which suggests that Sphagnum can continue to decolorization under several cycles of reuse. For this reason, moss may be use constantly for decolorization of wastewater. Figure $4 \mathrm{~b}$ shows the remaining colors at the end of each reusability experiment.

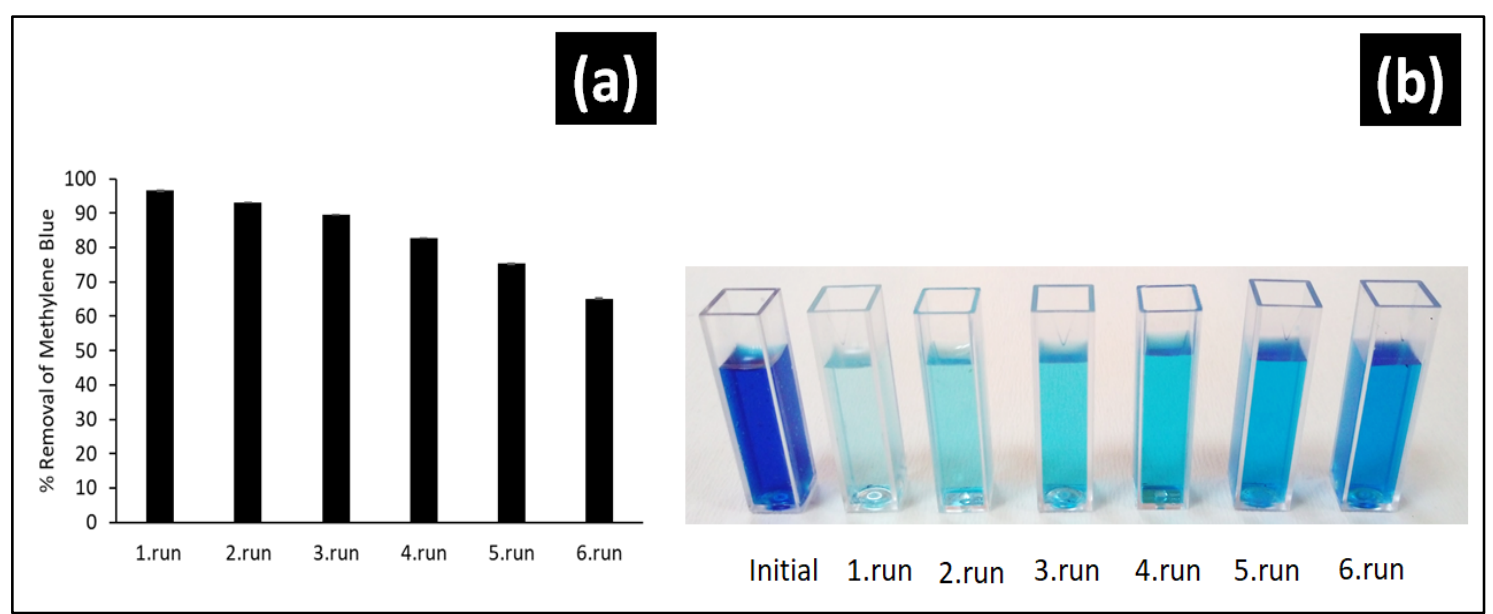

Figure 4. (a) Reusability results of the six cycles of MB decolorization experiments at $50 \mathrm{mg} \mathrm{L}^{-1}$ dye concentrations (b) the photographs of color after reusability experiments.

The Freundlich, Langmuir, Toth and Linear adsorption isotherm models were used for the experimental equilibrium sorption analyses and the best-fit equilibrium model was established based $\mathrm{R}^{2}$ that correspond to linear regression correlation coefficients. Adsorption isotherms and their values were listed in Table 1 . Results from these experiments were modelled adsorption isotherm theories with the Langmuir model proving to be the more suitable. The Langmuir isotherm theory presume monolayer coverage of adsorbate over a homogenous adsorbent surface (San Keskin et al., 2015). Similar results was reported by Allen et al., (1988). 
Table 1. Dye adsorption kinetics coefficients of $S$. palustre for each isotherm model

\begin{tabular}{llccc}
\hline Material & Isotherm & Parameters & Values & $\mathbf{R y}^{2}$ value \\
\hline & Freundlich & $\mathrm{Kf}$ & 0.015 & 0.97 \\
S. palustre & $\mathrm{1} / \mathrm{n}$ & 0.7 & 0.98 \\
& Langmuir & $\mathrm{Q}_{\max }$ & 2.49 & \\
& & $\mathrm{~b}$ & 1.92 & 0.92 \\
& Linear & $\mathrm{Kp}$ & $2.5 \times 10^{-2}$ & 0.93 \\
\hline
\end{tabular}

\section{Result and Discussion}

$S$. palustre moss was utilized as an adsorbent for the decolorization of methylene blue (MB) from aqueous solutions as a function of solution $\mathrm{pH}$ value, temperatures, static/shaking conditions, contact time, adsorbent dose and initial dye concentrations. Results obtained from experiments showed that the highest percentages of dye removal were attained using moss from pH 4.0 with $\mathrm{MB}$ concentrations below $50 \mathrm{mg} \mathrm{L}^{-}$

S. palustre was chosen as a suitable adsorbent which have pore structure that was capable of decolorization of dyes in wastewater. Due to large usage in textile industry MB was chosen as the target contaminant. After dye removal process, moss was reused six cycles and at the end of the last cycle, $65 \%$ of the MB dye decolorization capacity was obtained. $6^{\text {th }}$ cycle reusability suggest that moss utilized repeatedly for dye decolorization in wastewater such as industrial origin.

\section{Acknowledgements}

The authors thank Mr. Hikmet Can for the technical assistance provided.

\section{Conflict of interest}

The authors declare no conflict of interest.

\section{References}

Allen S.J. McKay G. Khader K.Y.H. 1988. Multi-component sorption isotherms of basic dyes onto peat. Environmental Pollution. 52: 39-53.

Argun M.E. Dursun S. Karatas M. Gürü M. 2008. Activation of pine cone using Fenton oxidation for $\mathrm{Cd}$ (II) and $\mathrm{Pb}$ (II) removal. Bioresource Technology. 99:18, 8691-8698.

Atafar Z. Mesdaghinia A. Nouri J. Homaee M. Yunesian M. 2010. Effect of fertilize application on soil heavy metal concentration. Environmental Monitoring and Assessment. 160-183.
Balan C. Bilba D. Macoveanu M. 2009. Studies on chromium (III) removal from aqueous solutions by sorption on Sphagnum moss peat. Journal of the Serbian Chemical Society. 74:8-9, 953-964.

Chakraborty S. De S. Basu J. K. Das Gupta S. 2005. Treatment of a textile effluent: application of a combination method involving adsorption and nanofiltration. Desalination. 174: 73-85.

Contreras E.G. Martinez B.E. Sepúlveda L.A. Palma C.L. 2007. Kinetics of basic dye adsorption onto Sphagnum magellanicum peat. Adsorption Science \& Technology. 25:9, 637-646.

Daniels R.E. Eddy A. 1985. Handbook of European Sphagna, Natural Environment Research Council, Institute of Terrestrial Ecology, Huntington.

Du J. Zhang L. Gao H. Liao Y. 2016. Removal of Methylene Blue from aqueous solutions using Poly (AA-co-DVB). Journal of Dispersion Science and Technology. 1489-1494.

Garg V.K. Gupta R. Yadav A.B. Kumar R. 2003. Dye removal from aqueous solution by adsorption on treated sawdust. Bioresource Technology. 89: 121-124.

Ghaedi M. Mosallanejad N. 2014. Study of competitive adsorption of malachite green and sunset yellow dyes on cadmium hydroxide nanowires loaded on activated carbon. Journal of Industrial and Engineering Chemistry. 20: 1085-1096.

Gupta B.S. Curran M. Hasan S. Ghosh T.K. 2009. Adsorption characteristics of $\mathrm{Cu}$ and $\mathrm{Ni}$ on Irish peat moss. Journal of Environmental Management. 90: 954960.

Gupta V.K.S. 2009. Application of low-cost adsorbents for dye removal-A review. Journal of Environmental Management. 90: 2313-2342.

Hajati S. Ghaedi M. Yaghoubi S. 2014. Local, cheap and nontoxic activated carbon as efficient adsorbent for the simultaneous 
removal of cadmium ions and malachite green: optimization by surface response methodology. Journal of Industrial and Engineering Chemistry. 21: 760-767.

Hemmati F. Norouzbeigi R. Sarbisheh, F. Shayesteh H. 2016. Malachite green removal using modified sphagnum peat moss as a low-cost biosorbent: Kinetic, equilibrium and thermodynamic studies. Journal of the Taiwan Institute of Chemical Engineers. 58: 482-489.

Kazemi P. Peydayesh M. Bandegi A. Mohammad T. Bakhtiari O. 2013. Pertraction of methylene blue using a mixture of D2EHPA/M2EHPA and sesame oil as a liquid membrane. Chemical Papers. 67: 722-729.

Lee Y.C. Kim E.J. Yang J.W. Shin H.I. 2011. Removal of malachite green by adsorption and precipitation using amino propyl functionalized magnesium phyllosilicate. Journal of Hazardous Materials. 192: 62-70.

Malik A. 2014. Metal bioremediation through growing cells. Environment International. 30: 261-278.

Marrakchi F. Bouaziz M. Hameed B.H. 2017. Adsorption of acid blue 29 and methylene blue on mesoporous $\mathrm{K}_{2} \mathrm{CO}_{3}$-activated olive pomace boiler ash. Colloids and Surfaces A: Physicochemical and Engineering Aspects. 535: 157-165.

Ören M. Uyar G. Ezer T. Gözcü M.C. 2017. New and noteworthy bryophyte records for Turkey and Southwest Asia. Telopea Journal of Plant Systematics. 20: 97-104.

Raghu S. Lee C.W. Chellammal S. Palanichamy S. 2009. Evaluation of electrochemical oxidation techniques for degradation of dye effluents a comparative approach. Journal of Hazardous Materials. 171: 748754.

Saeed A. Iqbal M. Zafar S.I. 2009. Immobilization of Trichoderma viride for enhanced methylene blue biosorption: batch and column studies. Journal of Hazardous Materials. 168: 406-415.

Saeed A. Sharif M. Iqbal M. 2010. Application potential of grape fruit peel as dye sorbent: kinetics, equilibrium and mechanism of crystal violet adsorption. Journal of Hazardous Materials. 179: 564572.

San N.O. Celebioglu A. Tümtaş Y. Uyar T. Tekinay T. 2014. Reusable bacteria immobilized electrospun nanofibrous webs for decolorization of methylene blue dye in wastewater treatment. RSC Advances. 4:61, 32249-32255.

San Keskin N.O. Celebioglu A. Uyar T. Tekinay T. 2015. Microalgae immobilized nanofibrous web for removal of reactive dyes from wastewater. Industrial and Engineering Chemistry Research. 54: 5802-5809.

San Keskin N.O. Celebioglu A. Sarioglu O.F. Ozkan A.D. Uyar T. Tekinay T. 2015. Removal of a reactive dye and hexavalent chromium by a reusable bacteria attached electrospun nanofibrous web. RSC Advances. 5:106, 86867-86874.

Schofield W.B. 2001. Introduction to Bryology, The Blackburn Press, Caldwell, USA, ISBN: 973-228-7077, pp. 431.

Soni A. Tiwari A. Bajpai A. K. 2014. Removal of malachite green from aqueous solution using nano-ironoxide loaded alginate microspheres: batch and column studies. Research on Chemical Intermediates. 40: 913-930.

Toor M. Jin B. Dai S. Vimonses V. 2015. Activating natural bentonite as a costeffective adsorbent for removal of Congored in wastewater. Journal of Industrial and Engineering Chemistry. 21: 653-661.

Turabik M. Gozmen B. 2013. Removal of basic textile dyes in single and multi-dye solutions by adsorption: statistical optimization and equilibrium isotherm studies. Clean. 41:11, 1080-1092.

Wagner H. Siebert T. Ellerby D.J. Marsh R.L. Blickhan R. 2005. ISOFIT: a model-based method to measure muscle-tendon properties simultaneously. Biomechanics and Modeling in Mechanobiology, 4:1, 10-19.

Wang S. Zhu Z.H. Coomes A. Haghseresht F. Lu G.Q. 2005. The physical and surface chemical characteristics of activated carbons and the adsorption of methylene blue from wastewater. Journal of Colloid Interface Science. 284: 440-446.

Zaghbani N. Hafiane A. Dhahbi M. 2007. Separation of methylene blue from aqueous solution by micellar enhanced ultrafiltration. Separation and Purification Technology. 55: 117-121. 